\title{
Tradução do Texto Grego do Horário como Unidade Autônoma do Testamento de Adão
}

\author{
Milton Luiz Torres*, Ana Maria Moura Schäffer ${ }^{* *}$, Deleon Ferreira de Lima ${ }^{* * *}$
}

\begin{abstract}
RESUMO: A proposta de tradução do texto grego do Horário para o português teve o objetivo de responder a questões relevantes relacionadas com a obra: que evidências apontam para uma autoria gnóstica? Por que pode ser tratada como obra autônoma, mesmo sendo parte integrante do assim-chamado Testamento de Adão? Além da tradução, comentou-se o gnosticismo de Nag Hammadi e fez-se uma comparação breve com a literatura apocalíptica judaica do século I A.D. Concluiu-se, ao final, que seu dualismo, ênfase no repouso e natureza heterodoxa contribuem para a identificação gnóstica da obra e confirmam seus contatos com a literatura apocalíptica judaica do século I A.D.
\end{abstract}

Palavras-chave: Horário; Testamento de Adão; gnosticismo; Adão; dualismo.

ABSTRACT: This translation of the Greek text of the Horarium into Portuguese intended to answer relevant questions related to the work: what types of evidence point to a Gnostic authorship? Why can it be treated as an autonomous work, even though it is an integral part of the so-called Testamentum Adami? In addition to the translation, Nag Hammadi's gnosticism was commented on and compared with first-century A.D. Jewish apocalyptic literature. It was concluded, in the end, that its dualism, emphasis on rest and heterodox nature contribute to the identification of the work as Gnostic and confirm its contacts with first-century A.D. Jewish apocalyptic literature.

Keywords: Horarium; Testamentum Adami; Gnosticism; Adam; dualism.

Apesar de o Horário ser uma obra de grande valor histórico para a compreensão do cristianismo primitivo, ela ainda continua sendo relativamente pouco usada em países de língua portuguesa. Assim, o objetivo aqui é apresentar uma tradução da obra para o português, e responder a questões relevantes relacionadas a ela. Que evidências apontam para uma autoria gnóstica? Por que o Horário pode ser tratado como uma obra autônoma, mesmo sendo parte integrante do assim-chamado Testamento de Adão? Na tradição judaico-cristã primitiva, existia uma compreensão de que havia uma

\footnotetext{
* Mestre em Filologia Clássica pela University of Texas System (2001) e em Letras e Linguística pela Universidade Federal da Bahia (1995). Doutor em Arqueologia Clássica pela University of Texas System (2008), em Letras Clássicas pela USP (2014) e pós-doutor em Estudos Literários pela Universidade Federal de Minas Gerais (2009). Professor permanente do Mestrado Profissional em educação do UNASP-EC.

** Mestre em Linguística Aplicada pela Universidade Estadual de Campinas (2000). Doutora em Linguística Aplicada (UNICAMP). Professora dos Cursos de Letras e Tradutor (UNASP-EC) e professora Colaboradora do Mestrado Profissional em Educação (UNASP-EC).

** Graduado na Faculdade Adventista da Bahia (2009). Bacharel em Teologia (SALT-IAENE).
} 
organização de horas do dia e da noite no céu. Por isso, o texto grego do Horário fornece um pano de fundo contra o qual se podem compreender as referências bíblicas às horas (Ap 9:15; 14:7 e 18:10, por exemplo).

O texto pode ter sido originalmente escrito em siríaco (ROBINSON, 1983, p. 990). No entanto, a versão grega é de antiguidade indiscutível. Diante da falta de consenso absoluto, e como os estudos anteriores (ROBINSON, 1983, p. 990) privilegiaram, principalmente, o texto siríaco, é preciso também divulgar o texto grego, embora este seja mais compacto. O Testamento de Adão consta de três seções: o Horário, a Profecia e a Hierarquia. O foco desta tradução e comentário é o texto grego da primeira seção, comparável aos textos canônicos da Bíblia Hebraica $(\mathrm{BH})$ e do Novo Testamento (NT).

\section{História do Texto}

Depois da descoberta de uma biblioteca no Egito com 52 escritos em copta, em 1945, conhecida como Nag Hammadi, o gnosticismo tornou-se um centro de debate (STEWART, 1972, p. 2.940). Além disso, o gnosticismo se encontra em franca expansão, apelando principalmente às pessoas cultas e místicas (HARE, 2010). Sendo assim, o estudo do Horário se mostra de relevância, pois é possível que lance luz sobre a história do cristianismo primitivo, especialmente sobre a seita cristã dos gnósticos, ajudando a entender sua literatura e tornando-se relevante também para a compreensão da apocalíptica judaico-cristã.

Mesmo diante dos benefícios aqui sugeridos, o estudo do texto do Horário foi negligenciado por vários anos. O interesse pelo texto só foi despertado no século XIX, quando se percebeu que era uma obra gnóstica dos primeiros séculos (RENAN, 1853, p. 428). Uma explicação para essa negligência é o absurdo título pseudepígrafo (RENAN, 1853, p. 28), que atribui a obra a uma pessoa de grande destaque com o fim de valorizála, embora se desconheça o autor real. A pseudepigrafia é um fenômeno comum justamente porque tem a capacidade de propor autores plausíveis. O caso de uma autoria adâmica para a obra em questão parece, porém, fora de cogitação, mesmo para os leitores mais crédulos.

Com relação à língua original da obra, existem três possibilidades: o hebraico, o grego e o siríaco (ROBINSON, 1983, p. 990). A evidência em favor do hebraico vem do manuscrito grego, em que nomes hebraicos aparecem para designar as horas. Contudo, não passam de nomes gregos em caracteres hebraicos (ROBINSON, 1983, p. 990). Nau (1907, p. 167) acredita que Apolônio de Tiana a escreveu, sendo o grego sua língua original. Esse argumento não é aceito, porém, pela maioria dos estudiosos. Robinson (1983, p. 990) rebate a autoria grega já que nenhum dos manuscritos gregos é anterior ao século XVI. De fato, os estudiosos estão mais dispostos a aceitar o siríaco como língua original da obra.

No Horário, Adão mostra para seu filho Sete como é feita a divisão das horas no céu, e o que acontece em cada uma delas. Na Profecia, Adão conta para Sete como Deus criou o céu e a terra, dá detalhes sobre o dilúvio, seu pecado e o de sua mulher, Eva, até prever o final do mundo com a vinda do Messias. Finalmente, na Hierarquia, a obra apresenta uma lista de nove diferentes ordens de seres celestiais.

Alguns estudiosos defendem que as três partes do Testamento de Adão não foram escritas na mesma época (ROBINSON, 1983, p. 990), mas que houve uma redação final no meio ou no fim do século III, com base em três argumentos. Primeiro, a obra tem familiaridade com as tradições encontradas no NT. Segundo, parte da Profecia é citada no Transitus Mariae, que é datado no século IV. E, por último, a obra mostra uma relação com o Apocalipse de Elias. 
Houve demora no estudo do Testamento de Adão. Em 1853, foram publicados dois manuscritos siríacos, quatro manuscritos árabes e foi feita uma tradução francesa (RENAN, 1853). Em 1906, divulgaram-se uma nova versão árabe e outra etíope (BEZOLD, 1906). Um ano depois, mais seis manuscritos com três recensões com uma tradução em latim foram divulgados (KMOSKO, 1907). Somente em 1893 o texto grego, conhecido desde 1615, foi publicado. Esse texto é igual ao dos dois primeiros fragmentos de Renan, mas ninguém se deu conta disso imediatamente. O texto grego, que inclui apenas o Horário, provém de um manuscrito mágico de Paris, cujo texto é atribuído a Apolônio, o mágico. Mais tarde, Nau (1907) descobriu mais três cópias do texto grego que o atribuem à obra Apotelesmata ("Talismãs"), de Apolônio de Tiana, onde aparece junto com os nomes dos signos dos zodíacos, os nomes das estações, as melhores horas do dia e da noite para os feitiços, as orações de invocação, os nomes dos anjos que presidem as quatro estações, os nomes dos ventos, os nomes dos anjos que governam o mar e as plantas, modelos de talismãs para o presságio com pássaros, para os incêndios e para se fabricar um espelho que revela o que se passa no céu e no inferno. Segundo Renan (1853, p. 435), todas essas seções fazem parte de liturgias gnósticas.

O gênero dos apocalipses ou testamentos árabes ou siríacos era comum entre os cristãos primitivos (RENAN, 1853, p. 428). Renan (1853, p. 429) reconhece a natureza gnóstica da obra com base em uma citação de Epifânio (Panarion ou Tratado das heresias 26.8), que a considera como tal (WILLIAMS, 1987). No entanto, outros supõem, ao contrário, que a obra tenha sido assim apreciada unicamente por causa do preconceito cristão, que a considerava "supersticiosa" e "indigna do cristianismo" (HORT, 1877, p. 37). Apesar disso, sua referência à criação material de Deus, uma ideia de conotação antignóstica, e as doutrinas do segundo fragmento (nascimento virginal de Cristo, sua morte, ressurreição e ascensão ao céu) são antípodas das teorias gnósticas.

Samuel de Ani (apud RENAN, 1853, p. 431) sugere que a história do texto do Testamento de Adão tenha iniciado na Armênia. Ele propõe que o texto tenha ali chegado em 590 A.D. através dos sírios seguidores de Nestório, descritos como "os homens da fala de mel". Embora os armênios anatematizassem os sírios, esses lhes traduziram e legaram seus livros gnósticos, entre os quais estavam o Testamento de Adão e as Penitências de Adão. Entretanto, a suposta citação do Testamento de Adão por Epifânio em seu Tratado das heresias 1.2; 26.8, no decreto do papa Gelásio (494) e nas Constituições apostólicas, mostra que a obra já era conhecida muito antes de sua chegada à Armênia (RENAN, 1853, p. 428).

Ao longo da história, vários nomes foram dados à obra. Jorge Sincelo (século IX) os menciona: Vida de Adão, Pequeno gênesis, Apocalipse de Adão, Testamento de Adão e Penitência de Adão. No século XI, Cedreno fez um resumo, em grego, da obra e citou os textos em que a palavra metanoia é sinônimo de apocalipse: Apocalipse de Adão, Penitências de Orígenes, Penitências de Cipriano, Penitências de Tiago e Mambre, o Testamento dos doze patriarcas e Pístis Sophia. Apesar disso, os manuscritos siríacos reconhecem a obra como testamento, enquanto o manuscrito Vaticano 164 chama de apocalipse (RENAN, 1853, p. 431). Dionísio de Telemar (século VIII), escrevendo em siríaco, apresentou uma crônica da literatura siríaca e fez um resumo, a exemplo de Cedreno, chamando-o de Extrato dos livros encontrados na caverna dos tesouros misteriosos de Adão, pai de nossa raça, e de seu filho Sete (RENAN, 1853, p. 432). Os historiadores árabes chamavam a obra de Caverna dos tesouros (RENAN, 1853, p. 433). O fato de a obra ser dividida em três partes talvez tenha causado essa confusão em relação ao título. Não é possível precisar, por isso, qual seria o título original da obra e até mesmo se existiu um título original. 
A autonomia do Horário em relação às demais partes constituintes do Testamento de Adão se percebe por vários fatores. A razão por que o texto grego circulou de forma independente pode não se dever ao processo de fragmentação do texto ao longo dos anos, mas ao fato de este ter sido assim compreendido desde o início. Não existe uma aparente relação entre as três partes da obra. Em palavras mais claras, não pode ser dito que o Horário seja a introdução, a Profecia seja o corpo, e a Hierarquia a conclusão de uma mesma obra; pelo contrário, as três seções do Testamento de Adão dificilmente seriam reconhecidas como sendo constituintes de uma mesma obra não fosse a tradição que as liga.

Finalmente, resta-nos investigar a natureza gnóstica do Horário. Como é nossa intenção tratá-lo como texto autônomo, não será preciso, portanto, invocar o testemunho dos demais fragmentos do Testamento de Adão, bastando concentrar nossa atenção na evidência interna proveniente do próprio texto grego. O texto grego do Horário apresenta características gnósticas, pois os gnósticos apresentavam a criação de uma forma dualista: luz versus trevas, espírito de Deus versus espírito do mal, conhecimento versus ignorância (RUDOLPH, 1975, pp. 57-59). Esses contrastes aparecem com frequência no Horário. Há um forte dualismo até na oposição entre o dia e a noite. Além disso, tome-se outro exemplo em 1.10, onde se diz: "a décima hora é aquela na qual o espírito de Deus paira sobre as águas e as santifica. Pois, se assim não fosse, os espíritos malignos prejudicariam as pessoas". Também há dualismo nas alusões aos anjos. Enquanto os anjos do bem intercedem em favor das pessoas (1.6a), os demônios, ou anjos do mal, ferem e causam dano (2.4a). Finalmente, há mais um exemplo de dualismo na oposição entre a luz e as trevas.

Outra característica presente na literatura gnóstica é a doutrina do repouso salvífico (BOCK, 2007, p. 88). Essa característica aparece no Horário 1.9a, que diz: "chama-se hora nona aquela * na qual as pessoas oram e nada se faz". Também em 1.6c se diz: "na sexta hora há o recolhimento dos anjos...". Portanto, a crença no repouso é algo que aparece no Horário e é mais um argumento em favor da autoria gnóstica da obra.

Finalmente, a denominação de horas também traz uma relação com 0 gnosticismo. O Evangelho de Filipe, obra gnóstica descoberta em Nag Hammadi, diz: "os nomes que se dão às coisas do mundo são susceptíveis de grandes enganos... Estes estão no mundo, se estivessem no céu não se chamariam como se chamam no mundo nem se achariam nas coisas terrenas; eles têm seu fim no céu" (OTERO, 1988, p. 717). Assim, conclui-se que, segundo o Evangelho de Filipe, é necessário que as coisas celestiais recebam novos nomes, pois os nomes terrenos são enganosos. Percebe-se, portanto, que a designação de cada uma das horas no Horário é mais uma característica gnóstica.

O fato de o Horário descrever a criação de forma exclusivamente material, ideia que é contrária ao pensamento gnóstico, requer análise à parte, pois o Horário é uma descrição de acontecimentos desde uma nova perspectiva, isto é, a celestial. Portanto, mesmo que haja alusões à criação, essa criação não acontece exatamente como é entendida no mundo material. Isso pode ser constatado pelo fato de que o Horário dá nomes novos às horas do dia e da noite. Apesar disso, pode-se dizer que a referência à criação, mesmo em um sentido original, permanece como o grande obstáculo para o consenso de que a obra seja gnóstica.

Depois de analisar as características do dualismo e da doutrina do repouso, pode ser sugerido que o Horário se enquadra no estilo da literatura gnóstica.

\section{A Tradução do Texto}


1.t As denominações das horas diárias.

1.1a Chama-se primeira hora aquela na qual é bom orar.

1.1c Na primeira hora do dia, faz-se a primeira oração no céu.

1.2a Chama-se segunda hora aquela na qual acontecem as orações dos anjos e hinos.

1.2c Na segunda [hora], há a oração dos anjos.

1.3a Chama-se hora terceira aquela na qual agradecem todas as aves a Deus. Na mesma hora todos os fundamentos são cumpridos.

$1.3 \mathrm{c} \mathrm{Na}$ terceira [hora], há a oração dos pássaros.

1.4a A hora quarta * em que agradecem todas as criaturas de Deus, na qual alinham-se (palavra ilegível em hebraico) e todos os animais peçonhentos.

$1.4 \mathrm{c} \mathrm{Na}$ quarta [hora], há a oração dos animais de carga.

1.5a Chama-se hora quinta aquela * em que todo animal louva a Deus; na qual tudo é concluído...

$1.5 \mathrm{c} \mathrm{Na}$ quinta [hora], há a oração das feras.

1.6a Chama-se hora sexta aquela * na qual os querubins intercedem a Deus em favor das pessoas.

1.6c Na sexta [hora], há o recolhimento dos anjos e a separação de cada criação.

1.7a A hora sétima * na qual louvam as hostes angélicas e os que servem a Deus.

1.7c Na sétima [hora], há a entrada dos anjos para Deus e a saída dos anjos.

1.8a Chama-se oitava hora.

$1.8 \mathrm{c} \mathrm{Na}$ oitava [hora], há o louvor e os sacrifícios dos anjos.

1.9 a Chama-se hora nona aquela * na qual as pessoas oram e nada se faz.

$1.9 \mathrm{c} \mathrm{Na}$ [hora] nona, há a oração e o culto do ser humano.

1.10a A hora décima é aquela * em que louvam as águas, e o Espírito de Deus, descendo, paira sobre elas e as santifica. Pois, se assim não fosse, os espíritos malignos prejudicariam as pessoas. [Nessa hora], se uma pessoa toma nardo e o mistura com óleo santo, ela cura toda doença. Ela purifica os endemoniados e os demônios.

$1.10 \mathrm{c} \mathrm{Na}$ décima [hora], há as visitas às águas e as orações dos seres celestiais e terrestres.

1.11a A hora décima primeira é aquela * na qual se regozijam os escolhidos de Deus.

$1.11 \mathrm{c} \mathrm{Na}$ [hora] undécima, há o pacto e a exultação de todos.

1.12a A hora duodécima é aquela * na qual são bem recebidas as preces das pessoas.

$1.12 \mathrm{c} \mathrm{Na}$ [hora] duodécima, há a intercessão das pessoas por boa vontade.

2.t $\{$ As denominações das horas noturnas. \}

2.1a A primeira hora é aquela * na qual os demônios que louvam a Deus nem transgridem nem castigam.

2.2a A segunda hora é aquela * na qual os peixes cantam hinos a Deus e também o faz a profundez do fogo; nela, os efeitos devem se alinhar para as serpentes e também (...) e fogo.

2.3a A terceira [hora] é aquela * na qual louvam as cobras, os cães e o fogo.

2.4a A quarta hora é aquela * na qual os demônios atravessam os cemitérios e o que vem ali será atingido e receberá o medo e o temor da aparição dos demônios.

2.5a A quinta hora é aquela * na qual as águas de cima louvam ao Deus do céu.

2.6a A sexta hora é aquela quando é necessário repousar e cessar, pois, há medo.

2.7a A hora sétima é aquela * na qual todos esses animais repousam. Se uma pessoa pura pega nardo e o sacerdote o mistura com óleo e o santifica, derramando-o sobre um doente insone, imediatamente será libertado da enfermidade.

2.8a A hora sétima é a aquela * na qual completamos [? devendo completar] o levantamento de todos os tipos de plantas.

2.9a A hora nona é aquela * na qual nada se faz. 
2.11a A hora décima-primeira é aquela * na qual se abrem as portas do céu e a pessoa, tomada de pesar, se tornará obediente; nessa [hora] abrem as asas com fragor os anjos, tanto os querubins, quanto os serafins, e há alegria no céu e terra. Então, nasce o sol do Éden.

2.12a A hora décima-segunda é aquela * na qual descansam as hostes ígneas.

\section{Interpretação e comentário}

O Horário é dividido em duas grandes seções: as horas do dia e as horas da noite, enumeradas em forma de capítulos e enfatiza conceitos de fundamental importância para o cristianismo: o louvor, a oração, a intercessão e o repouso. $O$ Horário mostra quando chega o momento em que cada uma das criaturas de Deus deve louvar, agradecer, interceder, orar e descansar, mostrando a adoração como central para a vida de cada criatura que respira.

A palavra grega hôra ("hora") que é usada em cada verso do Horário não é necessariamente um período de sessenta minutos. Contudo, o fato de o Horário apresentar, de forma sistemática, doze horas para o dia e doze horas para a noite, é um indicativo de que essas horas devem ser entendidas de forma literal. Mesmo assim, a literalidade das referências às horas não deve nos levar a pensar que estamos falando de sessenta minutos exatos. No inverno, a hora romana (medida em ampulhetas e relógios de sol) durava aproximadamente 45 minutos. Além disso, a latitude influenciava consideravelmente o ajuste dos relógios para a marcação do tempo.

1.1a A primeira linha serve de título. Logo em seguida, a primeira hora traz consigo o pensamento antigo de que o que vem primeiro tem sempre uma importância maior, assim como no caso do filho primogênito que tinha direitos especiais (Gn 27:4). Neste caso, a primeira hora do dia é a mais importante e, por isso, deveria ser dedicada à oração.

1.1c O termo usado para oração na primeira hora é a palavra grega eukê, que significa "voto", "oração", "prece”. Nos livros da Septuaginta (LXX), ela quase sempre é usada para designar um voto, enquanto nos livros no NT, que estão inseridos em contexto semelhante ao do Testamento de Adão, essa palavra quase nunca aparece, sendo usada apenas uma vez, em Tiago 5:15, onde seu significado é "oração". Portanto, no que se refere à primeira hora, "a primeira oração (ou voto) é feita no céu". Possivelmente, outra espécie de criatura que não seja um anjo é quem ora primeiro, pois a segunda hora é a das orações e louvores dos anjos. A palavra ouranos ("céu") deve ser entendida como o lugar onde Deus habita, pois o contexto mostra que é um lugar onde se fazem orações, cantam-se hinos, apresentam-se preces e realizam-se encantamentos. Portanto, apesar de a palavra "céu" poder se referir ao lugar onde estão os planetas, o contexto mostra que se trata do lugar da habitação de Deus.

1.2a-c A segunda hora se refere a uma espécie de culto a Deus, com a participação dos anjos.

1.3a-c Assim como os anjos têm o seu momento de adoração, as aves também agradecem a Deus. Essa parte da obra encontra paralelo com o Salmo 150, que diz que todo ser que respira deve louvar a Deus. A segunda parte do verso diz que "todo fundamento é cumprido". O termo stoicheion ("fundamento") também pode ser entendido como "princípio, regra". A palavra aparece no tema da primeira parte do primeiro capítulo das Antiguidades judaicas, de Josefo: hê tou kosmou systasis kai diátaxis tôn stoicheiôn, "a composição e disposição dos elementos do mundo". Trata-se, portanto, de uma expressão comumente associada com os processos criativos de Deus e Sua vontade para com os seres humanos e o universo. Assim, na mesma hora em que há o agradecimento das aves, cumprem-se todos os princípios que podem influenciar a vida 
das pessoas. Também há, aqui, a ideia de que as criaturas celestiais são capazes de influenciar a vida das outras criaturas de Deus.

1.4a-c Primeiramente acontecem as orações e agradecimentos dos anjos, das aves e, por último, o agradecimento de "todas as criaturas". O agradecimento dos "animais peçonhentos" é entendido como inferior ao das aves e dos anjos. Contudo, até os animais peçonhentos devem ter uma hora para louvar o Criador. Além disso, o texto traz uma palavra hebraica ilegível entre stoikeiountai ("alinham-se") e kai ta iobola ("todos os animais peçonhentos).

1.5a-c A presença de seres vivos como pássaros, animais de carga e animais peçonhentos, que entoam louvores e ações de graça no lugar onde Deus habita, é característica da literatura apocalíptica judaico-cristã do século I A.D. Tome-se, como exemplo, o texto:

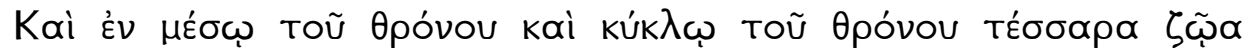

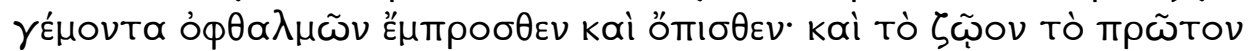

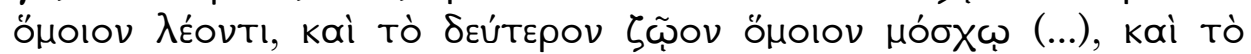

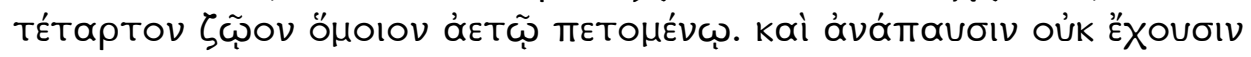

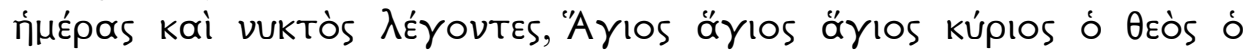

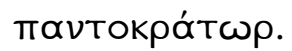

No meio e ao redor do trono, havia quatro animais cheios de olhos, tanto na frente quanto atrás. O primeiro animal parecia um leão, o segundo animal parecia um bezerro (...), o quarto animal parecia uma águia em voo (...). Eles não têm repouso, mas repetem dia e noite: - Santo, santo, santo é o Senhor, o Deus todo-poderoso (Ap 4:6-7).

Embora possa parecer estranho que um animal louve a Deus ou se comunique com a Divindade, não era assim no pensamento antigo. Uma evidência disso é o episódio, narrado em Gênesis 3, no qual a serpente fala com os seres humanos. Mencione-se, ainda, o caso da jumenta de Balaão, cuja boca Deus abriu (Nm 22:28). Na quinta hora, todas as coisas, ou obras, chegam ao fim. Essa pode ser mais uma alusão ao relato da criação, que diz: "assim, pois, foram acabados os céus e a terra e todo seu exército" (Gn 2:1). Embora a LXX use o verbo synteleô, trata-se sinônimo da forma apoteleitai, que aparece no Horário. Se adotarmos o sistema de contagem das horas do dia comumente utilizado no período helenístico, a quinta hora do dia seria equivalente às dez horas da manhã. Nessa perspectiva, o fato de as atividades matinais serem concluídas durante essa hora pode sugerir sua interrupção momentânea para o "almoço" (ariston).

1.6a O verbo dysôpeô ("interceder") também pode ser traduzido como "importunar", "envergonhar", "constranger alguém a fazer alguma coisa". Traduzido assim, esse verbo mostra de forma mais clara o que o texto quer dizer com "intercessão". Assim, na sexta hora os querubins "importunam" ou "constrangem" a Deus em favor das pessoas. Esse não é, porém, um termo que o NT usa comumente.

1.6c Na primeira parte do verso, há um momento em que os anjos se recolhem. $\mathrm{Na}$ segunda parte, há a "separação de cada criação". Essa ideia encontra paralelo no relato bíblico da criação, no qual Deus separa todas as coisas criadas e também cada uma delas é nomeada, ou discriminada, por Adão. Portanto, há, na sexta hora, o recolhimento dos anjos e também a discriminação, ou classificação de cada um dos seres criados, semelhantemente ao que ocorre no jardim do Éden logo após a criação (Gn 1;2:19). 
1.7a Na segunda hora, os anjos louvam e oram (1.2a). Novamente, na sétima hora, há "o louvor dos anjos e daqueles que servem a Deus". Há algumas repetições nas práticas litúrgicas dos seres que servem a Deus, quer sejam anjos, animais ou seres humanos. Essas repetições enfatizam que Deus é louvado continuamente por suas criaturas. Sempre é o momento de alguma criatura celestial ou terrena louvar a Deus. Esse pensamento encontra paralelo em Apocalipse 4:8, "dia e noite repetem sem cessar: - Santo, santo, santo é o Senhor, o Deus todo-poderoso, que era, que é e que há de vir".

1.7c Nesta parte do texto, faz-se alusão aos anjos que saem e entram no céu para prestar contas a Deus e executar missões que lhes são delegadas. $O$ pensamento de que os anjos têm acesso à presença de Deus aparece nas palavras de Jesus: "vede, não desprezeis qualquer desses pequeninos; porque eu vos afirmo que os seus anjos veem incessantemente a face de meu pai Celeste" (Mt 18:10). A sétima hora era, no período helenístico, o momento em que gregos e romanos interrompiam suas atividades corriqueiras para se dedicarem ao lazer. Um epigrama anônimo da Antologia grega (10.43) recomenda que a jornada de trabalho não ultrapasse as seis horas (MACKAIL, 1890). Por essa razão, a palavra grega zêthi (o imperativo "viva") continha, no sistema de numeração helenístico, os numerais que apontariam para as horas subsequentes à sexta, dedicadas ao lazer $(z=7, \hat{e}=8, t h=9$ e $i=10)$. Supondo que os gregos e romanos, bem como os povos sob sua influência, iniciavam o dia de atividades públicas muito mais cedo do que os povos ocidentais o fazem hoje, pode-se imaginar que o lazer grecoromano começava por volta do meio-dia. Durante esse período, é possível que os que temessem a Deus necessitassem de uma proteção mais atenta dos anjos, uma vez que os romanos gostavam de se entreter no circo, no anfiteatro, no teatro e nos balneários. Isso pode levar o autor do Horário a supor que, nesse momento, os anjos intensificassem suas entradas e saídas do céu.

1.8a Possivelmente, houve uma falha no processo de transmissão do manuscrito, o que deixou fragmentário este verso.

1.8c Nessa parte do texto, afirma-se algo que não é comum no cristianismo ortodoxo nem no gnosticismo: "o sacrifício dos anjos". Além disso, deve ser observada a ambiguidade no genitivo "dos anjos". Se o genitivo for considerado objetivo, deve ser entendido que os anjos são sacrificados. Se o genitivo for considerado subjetivo, os anjos louvam e sacrificam. Visto que a ideia de sacrificar anjos não é encontrada na $\mathrm{BH}$, nem no NT, e não é comum no gnosticismo, deve-se preferir a segunda interpretação. Considerando que os anjos sacrificam, a salvação não seria oferecida somente aos seres humanos, mas possivelmente também aos anjos.

1.9a Aqui são ressaltadas, mais uma vez, duas importantes doutrinas do cristianismo primitivo: a oração e o repouso, embora não sejam práticas exclusivamente cristãs. Há, por exemplo, uma passagem famosa nas Meditações, de Marco Aurélio, em que o imperador, como Cristo, ensina a orar (FORSTATER, 2001).

1.9c A hora nona provê evidência de que o autor do Horário imaginava ser possível estabelecer uma correspondência direta entre as horas que são marcadas no céu e aquelas que são marcadas na terra. A nona hora, no calendário romano, equivaleria, grosso modo, ao momento do sacrifício da tarde em Jerusalém. Talvez, por isso, essa hora é identificada como o momento do culto e da oração. Percebe-se, mais uma vez, a importância dessa doutrina. Nessa concepção, a oração não apenas faria parte do culto, mas seria uma prática a ser desenvolvida mesmo independentemente dele.

1.10a Neste verso, há, inicialmente, um paralelo com a criação, mas a criação de um ponto de vista gnóstico, pois se percebe uma dicotomia entre o Espírito de Deus e os demônios malignos. Segundo o verso, é necessário que o espírito de Deus paire sobre as águas para que os demônios percam seu poder de causar danos às pessoas, num 
dualismo característico da literatura gnóstica e da apocalíptica judaico-cristã. $\mathrm{Na}$ segunda parte do verso, fala-se de uma espécie de poção de nardo e óleo, para expulsar demônios e curar doentes. Talvez essa seja mais uma prática do gnosticismo, pois não se trata de um pensamento oficial do cristianismo ortodoxo. Tiago 5:15 diz que o doente deve ser ungido com óleo, mas "a oração da fé o salvará". Nesse caso, é o Senhor que o "levantará" e não simplesmente o uso de nardo com óleo. Muito menos Tiago recomenda um horário específico para a unção. Apesar disso, não se pode dizer, com certeza, que essa seria uma prática exclusivamente gnóstica.

1.10c A frase "visitas às águas" sugere que existe um momento de inspeção de tudo que habita nas águas. Nesse caso, Deus, além de Criador, é aquele que também cuida de Sua criação. A palavra episkopai ("visitas") também pode ser traduzida como "supervisão", "observação", "inspeção". Aqui há um paralelo com Gênesis 1:2, onde se diz que "o Espírito de Deus pairava sobre as águas", uma alusão direta ao relato da criação. É importante dizer que a LXX usa essa mesma palavra para se referir ao momento em que Deus executa algum tipo de juízo contra Israel, como, por exemplo, em Jeremias 6:15. No NT, Jesus usa a palavra episkopê para falar de sua vinda à Terra (Lc 19:44). Assim, Deus faz visitas com a finalidade de julgar os seres que habitam nas águas.

1.11a A organização celestial chega a um nível tão elevado que, até para regozijar-se, é necessário cumprir o horário. Além disso, o regozijo não é para todas as criaturas de Deus, mas somente para aqueles que são escolhidos. A palavra eklektoi aparece no NT para se referir àqueles que são chamados por Deus para a salvação (Mt 22:14).

1.11c- Há quase sempre, no Horário, uma adição de informação na segunda dimensão de uma hora. Na décima primeira hora, depois da exultação dos escolhidos, há um momento de todos se regozijarem.

1.12a-c O Horário continuamente ressalta as doutrinas da intercessão e da oração. Assim, a hora duodécima é novamente tempo de orar e de fazer um pacto com Deus, um paralelo com os escritos do NT (cf. 1 Ts 5:17).

2t No segundo capítulo do Horário, nomeiam-se as horas noturnas.

No relato da criação as trevas são chamadas de "noite", enquanto a luz é chamada de "dia" (Gn 1:5). Quando a BH fala de "trevas", está geralmente falando de "noite". No entanto, as trevas não adquirem um valor negativo explícito no relato bíblico da criação. Mesmo, porém, que, no relato da criação, Deus declare que tudo é "bom", Ele não declara que a noite é boa (Gn 1:4). Sendo assim, no pensamento da BH, a noite já assumia um valor negativo implícito. No Pentateuco, as trevas (ou noite) aparecem novamente com um significado negativo, representando uma praga vinda da parte de Deus (Êxx 21:10). Além disso, é durante a noite que Deus executa juízo contra aqueles que oprimem o povo, chegando a declarar que passaria, à noite, pelo Egito e feriria os primogênitos de Faraó (Êxx 12:12). Assim, conclui-se que, no Pentateuco, a noite era um período que tinha conotação negativa, representando, às vezes, um momento de juízo. No NT, o significado de "trevas" é quase sempre semelhante àquele do Pentateuco. O dualismo de João entre luz e trevas aparece, por exemplo, em sua primeira carta: "Deus é luz e nele não há treva nenhuma" (1 Jo 1:5).

2.1a Enquanto, na primeira hora diária, "é bom orar", a primeira hora noturna começa com uma alusão aos demônios, o que sugere uma oposição entre as duas horas, a primeira positiva, e a segunda, negativa, representando mais um reforço ao dualismo do texto. Em grego, o termo daimôn ("demônio", "gênio", "espírito") não significava 
necessariamente um ser maligno. Para isso, era preciso que viesse seguido do adjetivo "mau". No entanto, no NT, os demônios são sempre maus.

2.2a; 2.3a Esses versos contêm uma ideia da literatura poética da $\mathrm{BH}$ : que os seres inanimados exercem ações humanas como louvar e cantar, como, por exemplo, no Salmo 96:12. A palavra apotelesma ("efeito, resultado") pode remeter também à "influência dos astros" (PEREIRA, 199?, p. 76).

2.4a No pensamento cristão primitivo, os demônios habitavam os cemitérios (Mt 8:28). Entretanto, a BH e a literatura cristã primitiva, exceto em casos raros, não tratam de demônios sem que estes estejam ligados às pessoas. Portanto, acha-se, nessa porção do Horário, uma ideia que não é comum ao cristianismo tradicional, talvez mais uma reminiscência do pensamento gnóstico.

2.5a $\mathrm{Na}$ quinta hora, seres inanimados, como as águas, voltam a desempenhar ações humanas, inclusive louvando a Deus. Como se afirmou antes, esta é uma descrição comum nos livros poéticos da BH, especialmente Salmos (S1 96:12).

2.6a-2.7a Repete-se a doutrina do repouso, provavelmente para ênfase. No entanto, acrescenta-se um novo elemento: o pensamento de que há medo à noite, posto que a noite não é segura. Portanto, é melhor descansar. Essa ideia tem paralelo com João 9:4, onde se diz: "é necessário que façamos as obras daquele que me enviou, enquanto é dia; a noite vem, quando ninguém pode trabalhar." Também, em 2.7a, aparece uma construção semelhante à que aparece em 1.10a. Em 1.10a, diz-se: "nessa hora, se uma pessoa toma nardo e o mistura com óleo santo, ela cura toda doença. Ela purifica os endemoniados e expulsa os demônios". Em 2.7a, lê-se: "se uma pessoa pura pega nardo e o sacerdote o mistura com óleo e o santifica, derramando-o sobre um doente insone, este será imediatamente libertado da enfermidade".

2.8a Possivelmente, há, aqui, uma alusão à criação das plantas no relato de Gênesis. A palavra phytōn ("planta"), que está no genitivo plural, só aparece uma vez no Horário e no NT, onde ela não é usada no sentido literal, pois Jesus a usa para se referir às pessoas que ficariam de fora do reino de Deus (Mt 15:13). Entretanto, o contexto do Horário favorece a um uso literal da palavra. Devido ao fato de que o texto grego do Horário foi encontrado na obra mágica de Apolônio de Tiana, pode-se mesmo conjecturar que o autor grego supusesse que o autor do Horário estivesse se referindo a alguma forma de levantamento de plantas para uso medicinal.

2.9a Algumas vezes, o Horário apresenta informações de forma excessivamente resumida. Em 2.6a, diz-se que é necessário repousar, pois há medo. Em 2.9a, diz-se, porém, que é necessário repousar e não se apresenta nenhuma razão para isso. No entanto, a presença do asterisco no texto grego indica que houve uma perda no texto. Assim, talvez a razão para o repouso não tenha sido preservada. Semelhantemente à nona hora do dia, a nona hora da noite é um momento em que nada se faz.

2.11a Na imagem das portas abertas, há uma alusão a Jó 2:1, isto é, à reunião em que os anjos são chamados a prestar contas a Deus, e Satanás se apresenta juntamente com eles. Nessa mesma hora, ocorre outro dualismo, entre pesar e alegria.

2.12a Aqui, repete-se a ênfase na doutrina do repouso. Desta vez, são as classes de fogo que devem descansar. A expressão pyrina tagmata ("hostes ígneas") também pode ser entendida como "as hostes que manipulam fogo". Possivelmente, essas classes seriam seres semelhantes àqueles que aparecem em Apocalipse 16:8 e que são destinados a provocar fogo: "o quarto anjo derramou a sua taça sobre o sol, e foi-lhe dado queimar as pessoas com fogo". Assim, o Horário é concluído com o descanso das hostes ígneas, isto é, com uma das ideias mais relevantes do pensamento gnóstico: a ênfase no repouso. 


\section{Conclusão}

A primeira contribuição deste trabalho é definir o Horário como obra de caráter gnóstico. Na época em que os estudos anteriores foram feitos, os estudiosos não tinham acesso a tantas obras relacionadas ao gnosticismo quanto as que foram encontradas em Nag Hammadi. Depois dessa descoberta, ficaram claras as duas principais características gnósticas: dualismo e ênfase no repouso. O Horário se define como gnóstico justamente pelo dualismo (a oposição entre uma criação material e outra espiritual; entre o Espírito de Deus e os espíritos malignos; entre o dia e a noite; entre a luz e as trevas; e entre a alegria e o pesar) e pela ênfase no repouso. Pode-se argumentar que o repouso não é um pensamento exclusivamente gnóstico, mas deve-se notar que o cristianismo tradicional não dá tanta ênfase ao repouso quanto o gnosticismo. No cristianismo tradicional, o repouso é apenas uma doutrina adicional, enquanto que, no gnosticismo, essa ideia se transforma em uma característica distintiva. Finalmente, o Horário deve ser considerado como obra gnóstica devido à presença de alguns conceitos um tanto estranhos ao cristianismo ortodoxo. Tome-se como exemplo Horário 2.7 que apresenta uma espécie de simpatia usada para curar e expulsar demônios. Essa prática é diferente daquela que está registrada no NT, e praticada pelos cristãos primitivos (Mt 17:21). Portanto, há razões para crer que o Horário é, pelo menos, uma obra heterodoxa.

Se o Horário é uma obra gnóstica possivelmente escrita nos primeiros séculos, ele passa a ter certo valor para entender o gnosticismo e o cristianismo tradicional. $\mathrm{O}$ Horário mostra que o gnosticismo compartilhava vários aspectos com o cristianismo tradicional. O primeiro aspecto se relaciona com a literatura apocalíptica canônica. Trata-se do pensamento de que os eventos que estão relacionados com o céu são organizados em forma de horas, isto é que, existe um momento exato para que aconteçam (cf. Ap 9:15; 14:15 e 7; 18:10 e 19). Outro paralelo com o livro de Apocalipse é o pensamento de que o trono de Deus é habitado por seres que o louvam continuamente (cf. Ap 4:6-7). O Horário fundamenta a ideia de que Deus é louvado continuamente por suas criaturas, tanto na terra, quanto no céu. Essa ideia do louvor a Deus é, de fato, a ideia central da obra. Conclui-se, portanto, que a tradução do Horário contribui para sua identificação como obra gnóstica que apresenta contatos com a literatura apocalíptica do primeiro século.

\section{REFERÊNCIAS}

BEZOLD, C. Das arabisch-aethiopische Testamentum Adami: orientalische Studien zu Nöldekes so Geburtstage...gewidmet. Glessen: Töpelman, 1906. pp. 893-912.

BOCK, L. Darrel. Os evangelhos perdidos: a verdade por trás dos textos que não entraram na Bíblia. Rio de Janeiro: Thomas Nelson Brasil, 2007.

FORSTATER, Mark. The spiritual teachings of Marcus Aurelius. London: Coronet, 2001.

FREY, J. B. Adam: livres apocryphes sous son nom. In: PIROT, L. et al. (Eds.). Dictionnarie de la Bible. Paris: Letouzey et Ané, 1928. v. 1, pp. 117-125.

HARE, John Bruno. The Internet sacred text archive. 2010. Disponível em: <http://www.sacred-texts.com/gno/index.htm>. Acesso em: 23 mar. 2018. 
HORT, Nome. Adam, books of. In: SMITH, William; WACE, Henry. A dictionary of Christian biography, literature, sects, and doctrines. Londres: John Murray, 1877. v. 1, pp. 34-39.

KMOSKO, M. Testamentum Adae. Patrologia Syriaca. Paris: R. Graffin, 1907.

MACKAIL, J. W. Greek anthology: selections. London/New York: Longmans, Green \& Co., 1890.

NAU, F. Apotelesmata Apollonii Tyanensis. Patrologia Syriaca. Paris: R. Graffin, 1907.

OTERO, A. S. Los evangelios apócrifos. Madrid: Católica, 1988.

PEREIRA, Isidro. Dicionário grego-português e português-grego. Porto: Apostolado da Imprensa, 199?.

RENAN, M. Ernest. Fragments du livre gnostique intitulé Apocalypse d'Adam. Paris: Imperiale, 1853.

ROBINSON, S. E. Testament of Adam: a new translation and introduction. In: CHARLESWORTH, James H. (Ed.). The anchor Bible: the Old Testament pseudepigrapha. New York: Doubleday, 1983. v. 1, pp. 981-995.

RUDOLPH, Kurt. Gnosis und Gnostizismus. Wege der Forschung. Armstadt: Wissenschaftliche Buchgesellschaft, 1975. v. CCLXII.

STEWART, Zeph; NOCK, D. Arthur. Essays on religion and the ancient world. Oxford: Clarendon,1972.

WILLIAMS, Frank (Trad.). The Panarion of Epiphanius of Salamis. Leiden: Brill, 1987.

Data de envio: 25-03-2018

Data de aprovação: 02-07-2018

Data de publicação: 15-08-2018 